\title{
Large-scale patterns in internal bioerosion of Porites: cross continental shelf trends on the Great Barrier Reef*
}

\author{
Paul W. Sammarco', Michael J. Risk ${ }^{2}$ \\ ${ }^{1}$ Australian Institute of Marine Science, PMB No. 3, Townsville M. C., Queensland 4810, Australia \\ ${ }^{2}$ Department of Geology, McMaster University, 1280 Main St. W., Hamilton, Ontario, Canada L8S 4M1
}

\begin{abstract}
Internal bioerosion of the coral Porites lobata Dana (Coelenterata, Scleractinia) was examined on 5 reefs across the central region of the Great Barrier Reef, Australia: Orpheus Island, Britomart Reef, Rib Reef, Davies Reef, and Myrmidon Reef. Ninety corals were sliced into discs $\left(n_{t}=270\right.$ replicates\} and X-rayed to identify internal bioeroders and quantify the degree of bioerosion caused by each bioeroding group. Total internal bioerosion decreased significantly with distance offshore, across the continental shelf. Abundances of bivalves and sponges decreased the most significantly. Sponges were significantly lower on the outer shelf. Abundance of sipunculans and polychaetes showed only a nominal decrease across the shelf. Boring bivalves dominated the inshore area while the relative abundance of sponges increased with distance from shore. The relative abundance of worms (polychaetes and sipunculans) remained generally constant across the shelf. The explanatory hypothesis is offered that there may be a link between internal bioerosion and the already documented decreasing productivity and increased abundance of grazing fish with distance from shore. Three predictions are also made: (1) that observed changes in internal bioeroders may influence sediment composition across the continental shelf, with inshore sediments being more poorly sorted, and possessing more fines produced by internal bioeroders; (2) that offshore lagoonal sediments may have a greater contribution derived from grazing fish; and (3) that the observed higher levels of bioerosion inshore may increase susceptibility of corals there to dislodgement and fragmentation imposed by physical disturbance.
\end{abstract}

\section{INTRODUCTION}

Bioerosion can be an important factor controlling the resistance of corals to wave shock (Hein \& Risk 1975, Highsmith 1980b, 1981, 1982, Highsmith et al. 1980, Tunnicliffe $1978,1981,1983)$ and the rates and nature of sediment production (Rutzler 1975, Acker \& Risk 1985). It may also contribute to control of nutrient and gas fluxes on coral reefs (Zankl \& Multer 1977, Risk \& Kramer 1981, Bellamy \& Risk 1982, Risk \& Muller 1983, Tudhope \& Risk 1985). Scoffin et al. (1980) have stated that bioerosion can destroy reefs almost as fast as they are created (also see Highsmith 1981) and others have stated that it can affect the morphology of carbonate coastlines (Trudgill 1976a, b, Acker \& Risk 1985). The subject of bioerosion has been reviewed by Carriker et al. (1969), Risk \& MacGeachy (1978), and Hutchings

\footnotetext{
- Contribution No. 482, Australian Institute of Marine Science
}

(1986). Such destructive processes have received little attention compared with their constructive counterparts (Davies 1983).

Risk \& Sammarco (1982) demonstrated a significant correlation between degree of internal bioerosion in dead Acropora and reduced grazing pressure. It was suggested that 3 factors could possibly explain the observed phenomenon: (1) a decrease in levels of biological disturbance (sensu Dayton 1971, Sammarco 1980,1982 ) imposed by grazers on newly settled larvae of endolithic borers; (2) the presence of algae, serving as a refuge for bioeroders; and/or (3) food and nutrient levels possibly being higher in the associated algal turf and sediment (see Klumpp et al. 1988). Sammarco et al. (1986) demonstrated that undeterred fish grazing was also associated with high levels of external bioerosion of dead foliose corals (e. g. Pachyseris speciosa) Results of this experiment supported the hypothesis that biological disturbance may affect the internal 
bioeroder community. In addition, they demonstrated that predation may influence internal bioeroder community. They also demonstrated that predation may influence internal bioerosion by affecting population dynamics within the endolithic bioeroder community. A long-term ( $3 \mathrm{yr}$ ) experiment demonstrated that fish grazing did indeed alter the community composition of the bioeroder community (Sammarco et al. 1987). Boring by sponges with large exposed papillae (Cliothosa hancocki Topsent) increased significantly when grazing was reduced within damselfish territories, while more cryptic boring sponges decreased in abundance. In that experiment, total internal bioerosion did not vary with grazing pressure. The central Great Barrier Reef region is known to exhibit variations in abundances of grazing fish populations (Williams 1982, Williams \& Hatcher 1983, Russ 1984a, b, c), algae (Russ 1984a), and productivity or chlorophyll a concentrations (Ikeda et al. 1980, Revelante \& Gilmartin 1982, Sammarco \& Crenshaw 1984). Since previous bioerosion studies in this area and elsewhere have revealed either correlations or a functional relationship between these groups or processes and bioerosion (see above), the question arises as to whether concomitant changes in bioerosion might also be observed across the $120 \mathrm{~km}$ wide continental shelf in this region.

Here we have examined large-scale patterns in bioerosion across the continental shelf of the central region of the Great Barrier Reef. We present the results of this study, offer explanatory hypotheses concerning factors which might influence those patterns, and mention some predictions for effects of the observed community patterns on sediment production.

\section{MATERIALS AND METHODS}

Study sites. All sampling was carried out in the central region of the Great Barrier Reef. Five reefs were considered, spanning the breadth of the continental shelf: the fringing reef of Orpheus Island, and the 4 platforms reefs - Britomart Reef, Rib Reef, Davies Reef and Myrmidon Reef (Fig. 1). On Orpheus Island, sites were located on the southern end of Pioneer Bay, a protected, low energy environment on the lee side of the island. On the latter 4 reefs, sampling sites were defined as patch reefs in backreef environments. All corals were collected between 28 October and 2 November 1986

Orpheus Island is a high continental island located close to shore in intermittently highly turbid waters; it lies in the plumes of the Burdekin and Ross Rivers and is also subjected to resuspended sediments of these inshore waters (see Walker 1981, Ikeda et al, 1982, Sammarco \& Crenshaw 1984) (Fig. 1). This area is also characterized by relatively low wave energy, variable salinities and temperatures, a higher biomass of zooplankton, and higher chlorophyll a concentrations than in offshore waters (Sammarco \& Crenshaw 1984). Myrmidon Reef occurs at the outer edge of the continental shelf and is characterized by relatively clear waters, low variance in salinity and temperature, low zooplankton biomass, and chlorophyll a concentrations which are patchy in space and time (Andrews 1983, Sammarco \& Crenshaw 1984). Britomart, Rib, and Davies Reefs are mid-shelf reefs, with oceanic parameters intermediate in all respects between Orpheus Island and Myrmidon Reef.

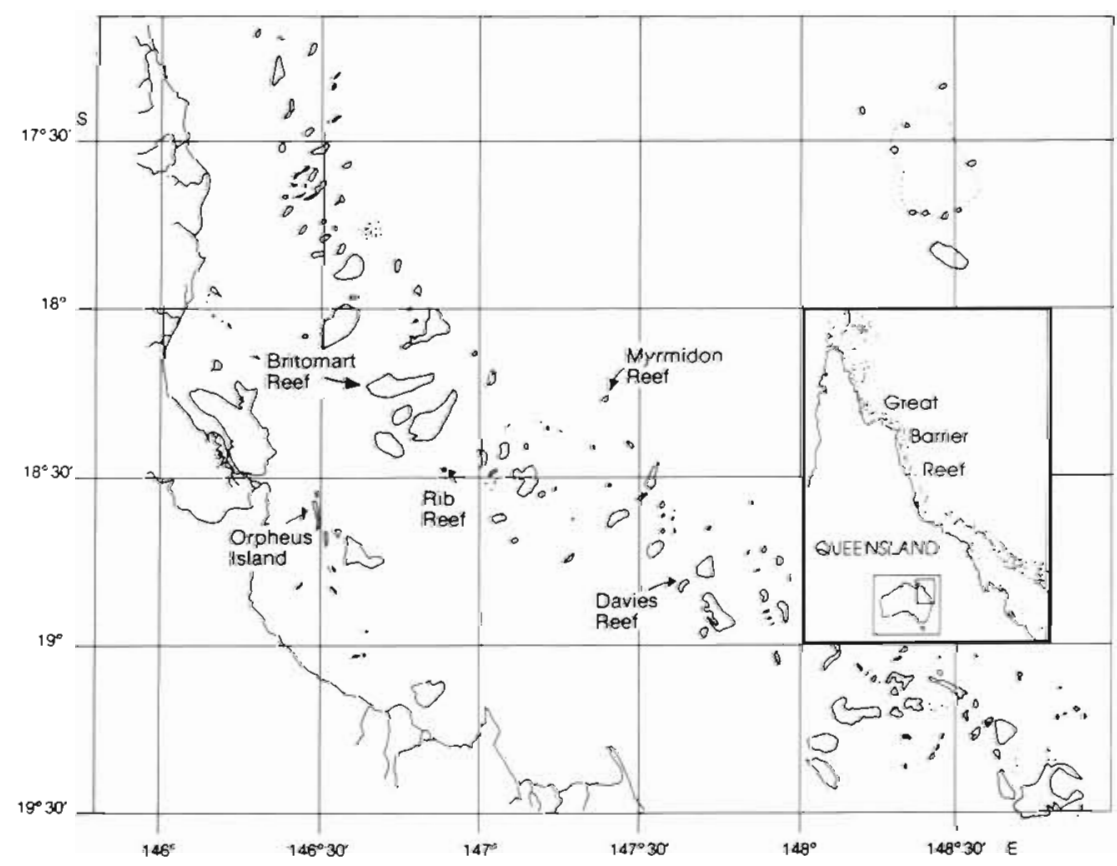

Fig. 1. Study area in central region of the Great Barrier Reef, depicting Orpheus Island, Britomart Reef, Rib Reef, Davies Reef, and Myrmidon (in order of increasing distance from shore) 
Sampling followed a Model I, 3-level, replicated nested ANOVA design. Six living heads of the scleractinian coral Porites lobata Edwards \& Haime, ca 20 to 30 $\mathrm{cm}$ in diameter, were sampled haphazardly from each of 3 sites on each reef at depths of 7 to $9 \mathrm{~m}$. P. lobata was chosen because it is widely distributed throughout the tropical Pacific and abundant to dominant across the continental shelf in this region of the Great Barrier Reef. In addition, the skeleton of Porites is relatively soft (Scott \& Risk 1988) and readily attacked by all groups of bioeroders. Only corals possessing $>80 \%$ intact living upper and lateral surfaces were chosen. Also, no corals occurring at $<0.5 \mathrm{~m}$ above the bottom sediment interface were collected, to avoid possible confounding effects of sediment on the bioeroder community.

From the center of each coral head, 3 serial slabs 1 $\mathrm{cm}$ thick were cut parallel to the axis of maximum growth with a rock-saw. Slabs were then X-rayed. $\mathrm{X}$ radiographs were printed and the areas of boring were quantified with a digitizer. Borers were identified to a relatively low degree of taxonomic resolution - such as bivalves, sponges, polychaetes, sipunculans, and barnacles. Since we were only interested in major trends in bioerosion over a large geographic range, data for polychaetes and sipunculans were analysed as a single group, to be referred to simply as 'worms' (Sammarco et al. 1987). The sponges Cliothosa hancocki and Cliona spp. were identified separately. Identification was made based on the shape, size, and character of each borehole, as described by Sammarco et al. (1987).
Data were analysed using standard parametric and non-parametric techniques with the aid of the Biometry Statistical Package (Sokal \& Rohlf 1981). Details of statistical analyses are presented in the figure and table legends. Higher order interactions will be mentioned and discussed only if significant.

\section{RESULTS}

The major taxa of bioeroders encountered in this study were bivalves (primarily Lithophaga spp.), sponges (particularly Cliothosa hancocki and Cliona sp.), polychaetes, sipunculans, and boring barnacles (primarily Lithotrya and other acrothoracicans; see Warme 1975). A brief description of the borehole characteristics associated with each group is given in Table 1, and X-radiographs depicting most of them may be found in Fig. 2. Further descriptions may be found in Sammarco et al. (1987).

Total percent bioerosion decreased significantly with distance from shore (Fig. 3). It averaged $11.0 \%$ at Orpheus Island and fell to $1.3 \%$ at Myrmidon Reef, on the outer edge of the continental shelf. Values for the 3 mid-shelf reefs were generally comparable to each other and were intermediate in value to those for Orpheus Island and Myrmidon Reef.

There was no significant difference in total bioerosion between sites within reefs (Tables $2 \mathrm{a}$, b). There was, however, a significant difference between coral

Table 1. Porites lobata. Description of boreholes of bioeroders as discerned by X-ray radiography. Table presents borehole description, location of boreholes within coral heads, and comments on their general occurrence

\begin{tabular}{|c|c|c|c|}
\hline Taxon & Borehole description & $\begin{array}{l}\text { Location of boreholes within } \\
\text { coral heads }\end{array}$ & General occurrence \\
\hline Lithophaga & $\begin{array}{l}\text { Cylindrical to elliptical (date- } \\
\text { shaped), sometimes with } \\
\text { meniscate false-floors }\end{array}$ & $\begin{array}{l}\text { Usually radiate up and out from } \\
\text { interior of head; often penetrat- } \\
\text { ing live coral surface }\end{array}$ & Dominating inshore reefs \\
\hline Cliothosa hancocki & $\begin{array}{l}\text { Spherical or elliptical to irregu- } \\
\text { lar galleries, in which all the } \\
\text { coral skeleton is removed }\end{array}$ & $\begin{array}{l}\text { Usually restricted to sides and } \\
\text { undersides of heads; some- } \\
\text { times penetrating live coral sur- } \\
\text { face }\end{array}$ & $\begin{array}{l}\text { Abundant to common inshore; } \\
\text { dominating the offshore boring } \\
\text { fauna. }\end{array}$ \\
\hline $\begin{array}{l}\text { Cliona sp. (the C. viridis } \\
\text { species complex) }\end{array}$ & $\begin{array}{l}\text { Reticulated, ramifying to ver- } \\
\text { miform galleries in which all } \\
\text { skeleton is not removed (soap- } \\
\text { suds appearance) }\end{array}$ & $\begin{array}{l}\text { Usually restricted to sides and } \\
\text { undersides of heads; can over- } \\
\text { grow and kill live corals }\end{array}$ & Present to common at all sites \\
\hline Polychaetes & $\begin{array}{l}\text { Long, meandering holes of sev- } \\
\text { eral diameters, or small U- } \\
\text { shaped to convoluted borings }\end{array}$ & $\begin{array}{l}\text { Typically unrestricted in loca- } \\
\text { tion. Can penetrate live coral } \\
\text { tissue }\end{array}$ & Present to common at all sites \\
\hline Sipunculans & $\begin{array}{l}\text { Relatively large elongated } \\
\text { flask-shaped borings }\end{array}$ & $\begin{array}{l}\text { Usually restricted to sides and } \\
\text { undersides of coral heads }\end{array}$ & Present to common at all sites \\
\hline Barnacles & $\begin{array}{l}\text { Conical, smoothly tapering } \\
\text { boreholes with constricted } \\
\text { openings }\end{array}$ & $\begin{array}{l}\text { Usually open through living } \\
\text { coral tissue }\end{array}$ & $\begin{array}{l}\text { Found only on Davies Reef here } \\
\text { (mid-shelf) }\end{array}$ \\
\hline
\end{tabular}



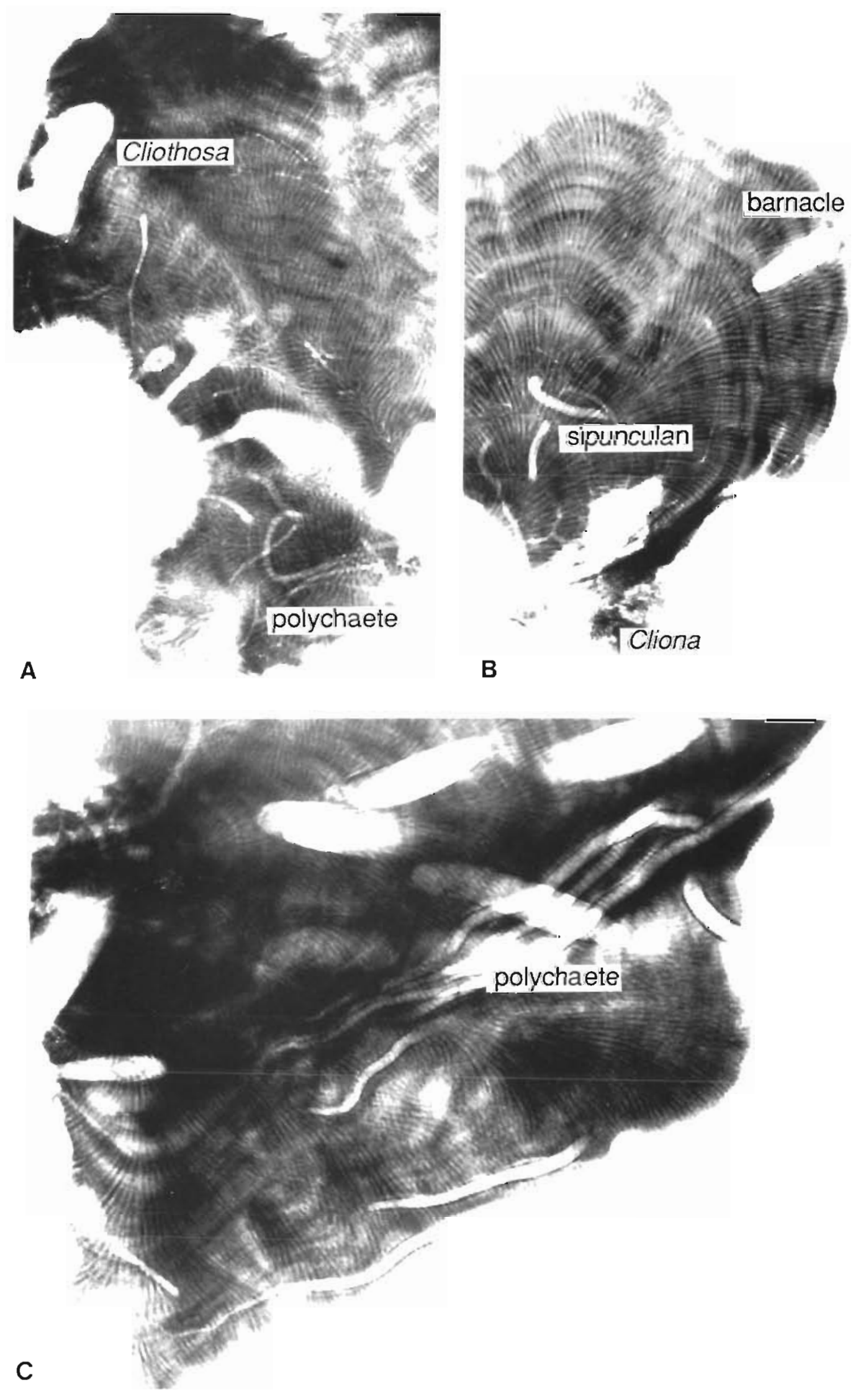

Fig. 2. Porites lobata. X-rays depicting various taxa of bioeroders and their characteristic boreholes: (A) Cliothosa and polychaetes; (B) Cliona, a sipunculan, and a barnacle: and (C) another polychaete 


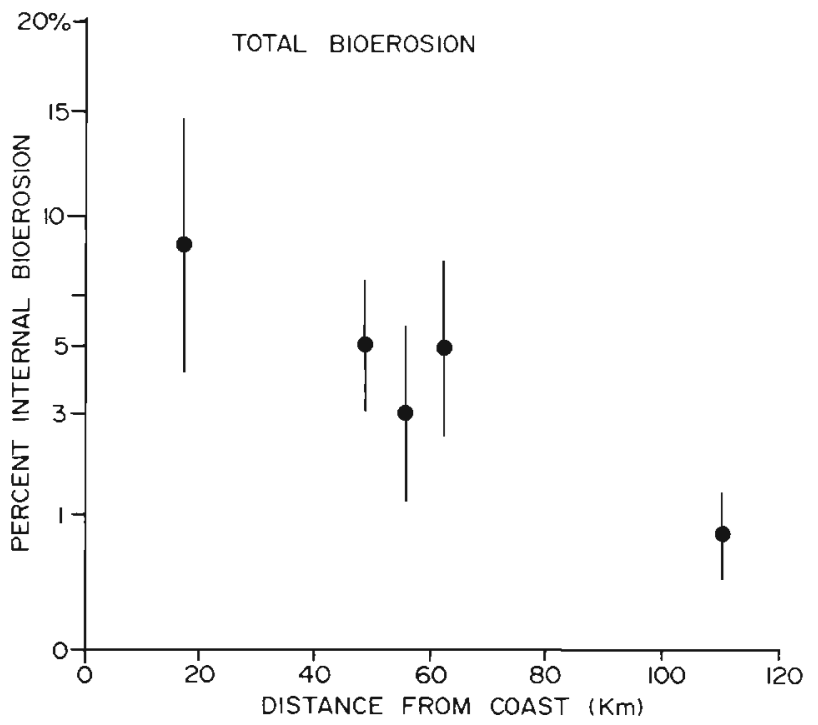

Fig. 3. Porites lobata. Total bioerosion found across the central Great Barrier Reef region on 5 reefs. Mean for all data pooled by reef $\left(n_{1}=54\right)$, shown with $95 \%$ confidence limits. Data transformed by arcsine for purposes of normalization (Sokal \& Rohlf 1981). Highly significant difference between reefs $(p<0.001,3$-level nested ANOVA; see Table 2a). Order of study sites, inshore to offshore: Orpheus Island and Britomart, Rib, Davies, and Myrmidon Reefs

Table 2. (a) Summary of statistical analyses of bioerosion data presented in Table 3. Data analyzed by 3-level, Model I nested ANOVA, using an arcsine transformation (Sokal \& Rohlf 1981). Data presented for total bioerosion and individual bioeroding taxa

\begin{tabular}{|c|c|c|c|}
\hline $\begin{array}{l}\text { Bioeroding } \\
\text { taxon }\end{array}$ & $\begin{array}{l}\text { Between } \\
\text { reefs }\end{array}$ & $\begin{array}{l}\text { Between } \\
\text { sites }\end{array}$ & $\begin{array}{c}\text { Between coral } \\
\text { heads }\end{array}$ \\
\hline Total bioerosion & $\cdots$ & ns & $\cdots$ \\
\hline Bivalves & $\cdots$ & ns & $\cdots$ \\
\hline Cliothosa & ns & $\mathrm{ns}$ & $\cdots$ \\
\hline Cliona & ns & $\cdots$ & $\cdots$ \\
\hline Total sponges & $\cdot$ & ns & $\cdots$ \\
\hline Worms & ns & ns & $\cdots$ \\
\hline
\end{tabular}

heads within sites, with over $50 \%$ of the total variance being accounted for by inter-head variance (Tables $2 b$ and 3). Although there was some variance between slabs within coral heads, it was not a major source of variance in the study.

The abundance of boring bivalves, particularly Lithophaga spp., declined significantly with distance from shore (Fig. 4), falling to less than $1 \%$ (percent area removed) by the mid-shelf. Infestation of Porites heads inshore by bivalves was highly variable. Even though the mean area bioeroded by Lithophaga in inshore waters was less than $3 \%$, some coral heads exhibited massive levels of infestation and excavation (Fig. 5), Bivalves exhibited essentially the same levels of intersite and inter-coral variance as that observed in total bioerosion (Tables $2 \mathrm{a}, 2 \mathrm{~b}$ and 3 ).

There was also a significant difference between reefs with respect to bioerosion levels of boring sponges as a group (Fig. 4). Sponges on Myrmidon Reef were particularly low in abundance. The distribution of variance components in sponge bioerosion also followed that observed in total bioerosion and bivalves, with intercoral variance being particularly high (Table $2 b$ ). When either Cliothosa hancocki or Cliona sp. were considered separately, however, no significant inter-reefal differences could be detected (Table 2a). Inter-coral levels of infestation were highly significant different not only in these 2 sponges but in all taxa considered. Cliona populations were significantly different between sites as well (Tables $2 \mathrm{a}, 2 \mathrm{~b}$ and 3 ).

Worms (sipunculans and polychaetes) were, overall, present in very low abundances. They exhibited no significant differences between reefs and no significant cross-shelf trend (Figs. 4 and 6).

Boring barnacles were absent or rare on the reefs considered here. The only reef in which they made up a measurable part of the bioeroder community was Davies Reef, and even there their abundance was negligible.

In considering bioeroder community structure as a whole, boring bivalves dominated the inshore reefs (Fig. 6). At the mid-shelf and outer shelf, this dominance

Table 2. (b) Percent contribution of each level of sampling to total variance measured in bioerosion of Porites lobata across the central region of the Great Barrier Reef

\begin{tabular}{lccccc|}
\hline Bioeroding taxon & Between reefs & Between sites & $\begin{array}{c}\text { Between coral } \\
\text { heads }\end{array}$ & Between slabs \\
\hline Total bioerosion & $23.8 \%$ & $0.0 \%$ & $57.6 \%$ & $18.6 \%$ & $100.0 \%$ \\
Bivalves & $21.4 \%$ & $0.0 \%$ & $57.6 \%$ & $21.0 \%$ & $100.0 \%$ \\
Cliothosa & $10.6 \%$ & $6.2 \%$ & $53.4 \%$ & $29.7 \%$ & $100.0 \%$ \\
Cliona & $2.9 \%$ & $14.1 \%$ & $32.2 \%$ & $50.7 \%$ & $100.0 \%$ \\
Total sponges & $15.2 \%$ & $0 \%$ & $56.6 \%$ & $28.2 \%$ & $100.0 \%$ \\
Worms & $3.8 \%$ & $7.2 \%$ & $49.3 \%$ & $39.7 \%$ & $100.0 \%$ \\
\hline
\end{tabular}


Table 3. Porites lobata. Quantitative estimates of internal bioerosion by endolithic bioeroders in colonies collected across the continental shelf in the central region of the Great Barrier Reef. Data represent percent area, calculated from digitizing $X$ radiographs of slabs; (see 'Materials and methods'). Data presented by site for total bioerosion as well as for that resulting from bivalves, Cliothosa, Cliona, total sponges, and 'worms' (polychaetes and sipunculans). The fringing reef of Orpheus Island was sampled; all other locations are platform reefs. Locations are presented in order of increasing distance from shore. Raw mean $(\bar{x})$, mean of data transformed by arcsine $\left(x_{1}\right)$, and standard deviation of same $\left(s_{t}\right)$ given. Each cell represents 6 corals with 3 replicate samples per coral; $\mathrm{n}_{\mathrm{i}}=18$

\begin{tabular}{|c|c|c|c|c|c|c|c|c|}
\hline \multirow{3}{*}{$\begin{array}{l}\text { Reef } \\
\text { (in order of increasing } \\
\text { distance from shore) }\end{array}$} & \multirow{3}{*}{\multicolumn{2}{|c|}{ Site }} & \multirow{3}{*}{$\begin{array}{c}\text { Total } \\
\text { bioerosion }\end{array}$} & \multicolumn{5}{|c|}{ Contributing bioeroding taxon } \\
\hline & & & & \multirow{2}{*}{ Bivalves } & \multicolumn{3}{|c|}{ Sponges } & \multirow[t]{2}{*}{ Worms } \\
\hline & & & & & Cliothosa & Cliona & Total sponges & \\
\hline \multirow[t]{9}{*}{ Orpheus Island } & 1 & $\bar{x}$ & $12.32 \%$ & $5.72 \%$ & $1.82 \%$ & $1.28 \%$ & $4.11 \%$ & 2.49 \\
\hline & & $\bar{x}_{t}$ & 18.80 & 10.49 & 5.68 & 4.38 & 9.67 & 6.66 \\
\hline & & $s_{\mathrm{t}}$ & 9.176 & 9.632 & 5.472 & 4.986 & 6.880 & 6.413 \\
\hline & 2 & $\overline{\mathrm{x}}$ & 8.274 & 2.12 & 1.11 & 0.27 & 1.93 & 4.22 \\
\hline & & $\bar{x}_{\mathrm{t}}$ & 15.21 & 4.81 & 5.04 & 1.68 & 6.76 & 10.13 \\
\hline & & $s_{r}$ & 7.59 & 7.158 & 3.492 & 2.568 & 4.489 & 6.55 \\
\hline & 3 & $\overline{\mathrm{x}}$ & 12.81 & 10.98 & 0.49 & 0.95 & 1.44 & 0.39 \\
\hline & & $\bar{x}_{t}$ & 16.85 & 12.45 & 2.60 & 3.87 & 5.64 & 2.92 \\
\hline & & $s_{t}$ & 14.352 & 16.407 & 3.170 & 4.172 & 4.110 & 2.162 \\
\hline \multirow[t]{9}{*}{ Britomart Reef } & 1 & $\bar{x}$ & 6.52 & 1.69 & 1.68 & 1.12 & 2.80 & 2.03 \\
\hline & & $\bar{x}_{t}$ & 14.06 & 5.67 & 5.43 & 2.88 & 7.54 & 6.05 \\
\hline & & $s_{t}$ & 4.985 & 5.055 & 5.295 & 5.597 & 6.269 & 5.727 \\
\hline & 2 & $\bar{x}$ & 6.385 & 1.64 & 0.01 & 2.61 & 2.69 & 2.05 \\
\hline & & $\bar{x}_{t}$ & 14.22 & 5.12 & 0.93 & 8.45 & 8.60 & 7.73 \\
\hline & & $s_{t}$ & 3.724 & 5.50 & 1.386 & 4.067 & 4.078 & 2.946 \\
\hline & 3 & $\overline{\mathrm{x}}$ & 4.74 & 1.35 & 1.08 & 0.52 & 1.60 & 1.79 \\
\hline & & $\bar{x}_{t}$ & 10.57 & 3.97 & 3.36 & 2.23 & 4.95 & 4.29 \\
\hline & & $s_{t}$ & 7.169 & 5.57 & 5.119 & 3.582 & 5.517 & 6.690 \\
\hline \multirow[t]{9}{*}{ Rib Reef } & 1 & $\overline{\mathrm{x}}$ & 6.82 & 0.55 & 4.83 & 0.17 & 5.01 & 1.26 \\
\hline & & $\bar{x}_{t}$ & 13.23 & 2.26 & 10.31 & 1.31 & 10.67 & 5.28 \\
\hline & & $s_{t}$ & 7.941 & 3.716 & 7.945 & 2.047 & 7.828 & 3.847 \\
\hline & 2 & $\overline{\mathrm{x}}$ & 4.66 & 0.93 & 1.13 & 1.54 & 2.68 & 1.05 \\
\hline & & $\bar{x}_{1}$ & 10.00 & 1.86 & 3.65 & 4.34 & 6.78 & 4.11 \\
\hline & & $s_{t}$ & 7.809 & 5.45 & 5.067 & 5.884 & 6.800 & 4.355 \\
\hline & 3 & $\overline{\mathrm{x}}$ & 2.27 & 0.18 & 1.53 & 0.00 & 1.53 & 0.55 \\
\hline & & $\overline{\mathrm{x}}_{\mathrm{t}}$ & 6.89 & 0.58 & 5.22 & 0.00 & 5.22 & 2.51 \\
\hline & & $s_{t}$ & 5.460 & 2.483 & 5.000 & 0.000 & 5.000 & 3.55 \\
\hline \multirow[t]{9}{*}{ Davies Reef } & 1 & $\overrightarrow{\mathrm{x}}$ & 7.98 & 0.56 & 3.66 & 1.44 & 5.10 & 2.32 \\
\hline & & $\bar{x}_{t}$ & 15.21 & 2.25 & 8.91 & 5.58 & 11.70 & 8.07 \\
\hline & & $\mathrm{s}_{\mathrm{t}}$ & 6.848 & 3.801 & 6.936 & 4.206 & 6.280 & 3.520 \\
\hline & 2 & $\overline{\mathrm{x}}$ & 4.70 & 0.26 & 2.06 & 0.86 & 3.16 & 1.35 \\
\hline & & $\bar{x}_{t}$ & 10.45 & 0.95 & 5.66 & 3.94 & 8.50 & 5.31 \\
\hline & & $s_{i}$ & 7.31 & 2.837 & 6.267 & 3.669 & 6.020 & 4.198 \\
\hline & 3 & $\overline{\mathrm{x}}$ & 6.51 & 0.42 & 1.39 & 0.89 & 5.00 & 1.10 \\
\hline & & $\overline{\mathrm{x}}_{\mathrm{t}}$ & 12.78 & 1.20 & 5.12 & 3.22 & 9.72 & 5.24 \\
\hline & & $s_{t}$ & 8.236 & 3.661 & 4.599 & 4.513 & 9.176 & 3.041 \\
\hline \multirow[t]{9}{*}{ Myrmidon Reef } & 1 & $\overline{\mathrm{x}}$ & 1.62 & 0.09 & 0.49 & 0.28 & 0.77 & 0.76 \\
\hline & & $\bar{x}_{t}$ & 5.95 & 0.87 & 2.54 & 1.84 & 3.76 & 3.41 \\
\hline & & $s_{t}$ & 4.413 & 1.565 & 3.215 & 2.466 & 3.447 & 3.777 \\
\hline & 2 & $\bar{x}$ & 0.89 & 0.00 & 0.12 & 0.20 & 0.32 & 0.60 \\
\hline & & $\bar{x}_{t}$ & 4.39 & 0.00 & 0.47 & 0.91 & 1.20 & 3.39 \\
\hline & & $s_{t}$ & 3.292 & 0.000 & 1.993 & 2.250 & 3.095 & 2.950 \\
\hline & 3 & $\bar{x}$ & 1.12 & 0.14 & 0.10 & 0.22 & 0.32 & 0.49 \\
\hline & & $\bar{x}_{t}$ & 4.56 & 0.73 & 0.90 & 1.62 & 2.05 & 2.84 \\
\hline & & $s_{t}$ & 3.387 & 2.122 & 1.621 & 2.240 & 2.608 & 2.914 \\
\hline
\end{tabular}




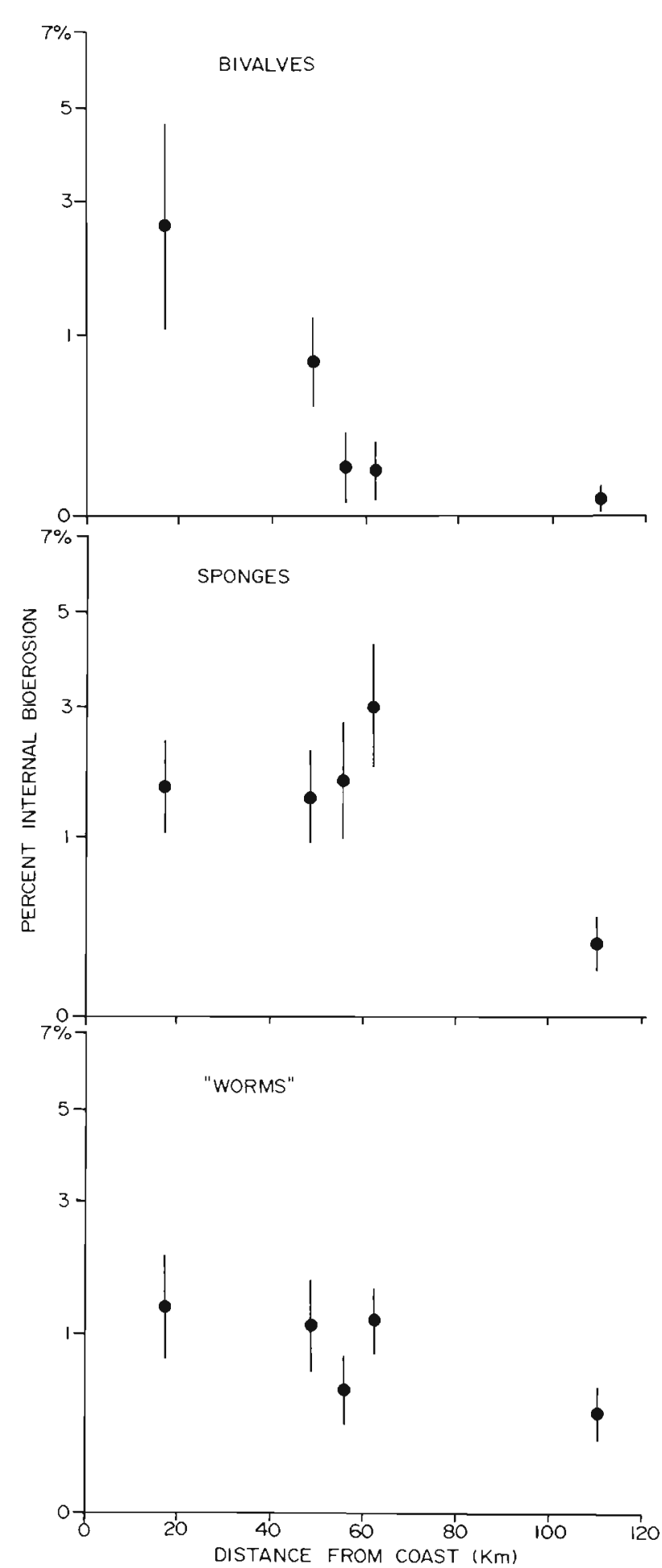

Fig. 4. Porites lobata. Bioerosion by individual taxonomic group expressed as percent. Mean for data pooled by reef, shown with $95 \%$ confidence limits. Bivalves; highly significant difference in bioerosion between reefs across continental shelf ( $p<0.01$, 3-level nested ANOVA; see Table 2a) Sponges; significant difference between reefs $(p<0.05)$ Worms; no significant difference between reefs $(p<0.05)$ shifted to the boring sponges as a group. The relative abundance of worms remained relatively constant across the shelf. Other bioeroders, including boring barnacles, had little or no influence on community structure.

\section{DISCUSSION}

There are a number of possible reasons for the significant decrease observed in total internal bioerosion with distance across the continental shelf. The major groups contributing to the observed increase inshore were bivalves and sponges, and this may be a response to increased availability of nutritional resources in inshore waters. Bivalves and sponges are filter-feeders, as are many other bioeroders. The productivity in inshore waters of continents and high islands is known to be higher than in open tropical waters (Zeitzschel 1978, Birkeland \& Grosenbaugh 1985, Birkeland 1987. in press). This is known to be the case on the Great Barrier Reef (Ikeda et al. 1980, Revelante \& Gilmartin 1982, Andrews 1983, Sammarco \& Crenshaw 1984), where chlorophyll a concentrations have been shown to be generally higher in inshore waters and in the plumes of the local rivers (e. g. the Burdekin River; Revelante \& Gilmartin 1982, Andrews 1983). Highsmith et al. (1983) hypothesized that a positive relationship existed between primary productivity and Lithophaga densities, and Scott \& Cope (in press) offered support for this. A similar relationship has been proposed to exist between bacterial content of seawater and abundance of boring sponges (Highsmith et al. 1983, Rose \& Risk 1985).

If these environmental factors and the observed trends in bioerosion are functionally related, then the implications for reef management are that eutrophication or increased productivity of reefal waters may promote increased levels of total internal bioerosion (also see Risk \& MacGeachy 1978, Highsmith 1980a, Hallock \& Schlager 1986, Hallock 1988). Internal bioerosion is a process which can proceed at high rates (Acker \& Risk 1985, Scott et al. in press), and appears to have been accelerated in such areas as Kaneohe Bay, Hawaii, which has in the past received extensive nutrient enrichment through organic pollution (Smith et al. 1981, S. V. Smith pers. comm.).

Another factor which may have influenced the abundance of boring sponges and bivalves is reduced grazing or predation. Williams (1982) and Williams \& Hatcher (1983) have shown that benthic grazing fish are less abundant in inshore waters in this area. Evidence has been presented which supports the hypothesis that grazing and predation on coral whether alive or dead, can influence endolithic infaunal community structure (White 1980, Risk \& Sam- 

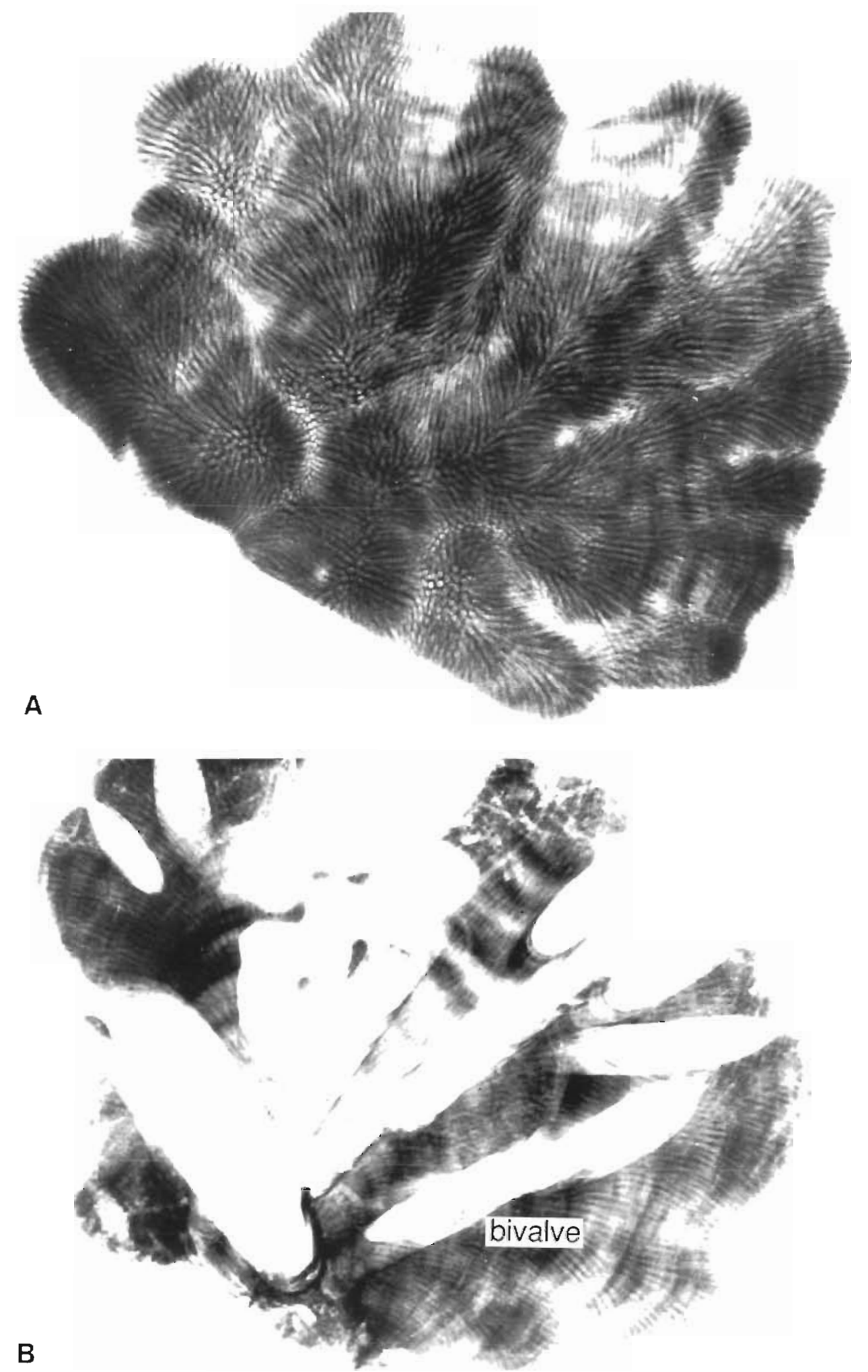

Fig. 5. Porites lobata. (A) Xray of a disc of coral sliced from sample from Myrmidon Reef on the edge of the continental shelf, $114 \mathrm{~km}$ from shore. (B) X-ray of a similarly sampled disc from Orpheus Island, a continental island only $14 \mathrm{~km}$ from shore. Bivalves were the primary bioeroders in this area

marco 1982, Sammarco et al. 1987). The decrease in relative abundance of bivalves further from shore may be due to increased levels of removal of newly settled juveniles and adults, whether through direct predation or biological disturbance (see Dayton 1971, Sammarco 1980, 1982). Guzman (1986) has described predation by balistids on Lithophaga living in Porites lobata on Costa Rican reefs. 


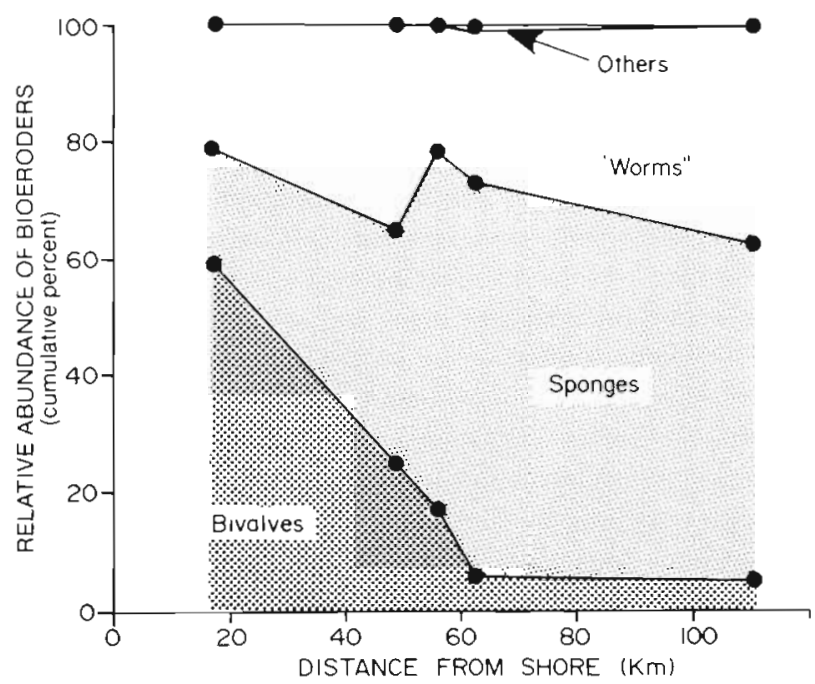

Fig 6. Porites lobata Relative abundance of major bioeloding groups detected on 5 reefs across the central region of the Great Bamer Reef Data shown in cumulative percent Note shifts in species composition across contmental shelf 'Others' refers to endolithic barnacles

It is possible that differential density of the coral skeleton could also have influenced degree of internal bioerosion. In a parallel study, we have determined that skeletal density of Porites lobata increases signiflcantly and linearly with distance from shore, across the continental shelf (R.sk \& Sammarco unpubl). These density data correlate negatuvely with the bioerosion data. This does not agree with data of Highsmith (1981) and Highsmith et al (1983) which show a positive correlation between internal bioerosion and skeletal density; those data, however, were derived from a sulte of scleractinian coral species from Enıwetak Atoll We believe that, although intraspecific variation in skeletal density may have assisted in deterring bioerosion on mid-and outer-shelf reefs, this would not be sufficient to fully explann the observed trends.

The relative abundance of sponges in the bioeroder community increased with distance from shore, but their absolute abundance was actually lower at Myrmıdon Reef. Bergman (1983) described changes in abundance of Chona vindis across Davies Reef, and attributed higher densities in backreef environments to increased bactenal concentrations Whether we are observing the results of a simlar relationship on a larger scale remains to be shown and confurmed expernmentally Unfortunately, no data are presently avallable on cross-shelf bactenal concentrations.

Our results are generally consistent with those of White (1980), who found that abundance of boring sponges increased under conditions of reduced grazing. She also found, however, that under high grazing pressure, corrallune algae proliferated isee Stencck 1982, 1983), overgrew the papillae of boring sponges, and killed them. Hel study was conducted on dead corals in Hawall, however, and may not be directly comparable to the results of this study, in which live corals were used

In this study, we observed several examples of infestation by Lithophaga which were so extensive that intraspecific competition for living space may have been occurring We are aware of only one case where internal competition for space has been documented tor 2 species of boring sponges (Rutzler \& Relger 1973). We believe that the question of competition for space, access to the water column, and food (sensu Buss 1980) in the endolithic bioeroding community under these conditions remains open and is deserving of further investigation.

In earlıer studies (Risk \& Sammarco 1982. Sammarco 1985. Sammarco et al. 1986, 1987), we suggested that a shift in grazing pressure would resuits in shifts in the broeroding communty which, in turn, would affect the type of seduments produced. We had suggested that, under conditions of reduced grazing pressure, there should be an increased contribution to the sediment of fine sands and silts characteristically produced by boring sponges. This would be coupled with large clasts produced durng high energy events derived from breakage of coral colonies weakened by bioerosion. The resulting sediments under such conditions might therefore be poorly sorted. Under conditions of high grazing pressure. a contribution to the sediment of well-sorted fine sands derived from external bıerosion by grazels would probably be more important.

It may be possible to broaden these concepts and place them into a cross-shelf framework. Based on data derived from this study, we would predict that lagoonal sediments of offshore reefs may be expected to have a lower concentration of fine sediments derived from internal bioerosional processes in comparison to inshore or midshelf reefs. We also predict that lagoonal. sediments of offshore reefs would possess a higher contribution of carbonate sands produced by grazıng tish, the major forces responsible for external bioerosion. Grazıng fish are known to produce prodigious amounts of sediment on reefs (Cloud 1959. Randall 1964, Gygl 1975, Ogden 1977, Frydl \& Stearn 1978). These biological processes, of course, represent only one set of processes among many contributing to the overall character of the sediment. In particular, physical processes must be taken into account. The importance of bloerosional processes in determining lagoonal sediment composition in relation to terngenous input, hydrography, bioturbation, currents, wave exposure, etc. remanns to be delermined.

High levels of boring bivalve infestation as observed in this study also weaken the corals and cause them to become easly detached from the substratum (Highsmith 1980b, Highsmith et al 1980). Because of 
increased levels of bioerosion, Porites lobata populations on inshore reefs may be inherently more susceptible to damage from catastrophic high energy events (e. g. storms and cyclones) than their offshore counterparts. It was suggested (Hein \& Risk 1975) and later verified (Tunicliffe 1981, 1983, Highsmith 1982) that extent of internal bioerosion in corals was a prime control of the coral's ability to resist wave shock.

The findings of this study may be summarized as follows: (1) Total internal bioerosion within the massive coral Porites lobata decreased significantly across the continental shelf of the central Great Barrier Reef. (2) Boring bivalves (Lithophaga) decreased in abundance with distance from shore. Abundance of boring sponges was significantly lower on the outer shelf than on the inner or mid-shelf. (3) The composition of the internal bioeroding community also changed across the continental shelf. Boring bivalves dominated inshore reefs; boring sponges dominated at the midshelf and offshore. Polychaetes and sipunculans remained relatively unchanged as a group with distance from shore. (4) We offer the explanatory hypothesis that changes in total bioerosion and bioeroder community composition may be due to decreased productivity and higher levels of predation and biological disturbance by the more abundant grazing fish populations with distance from shore. (5) We predict that lagoonal sediment of mid-and outershelf reefs in this region may a larger contribution of fine sands derived from activities of grazing fish than inshore reefs. Conversely, we predict that lagoonal sediments of inshore reefs may be expected to have a larger contribution of fine sands derived from internal bioerosion. We also predict that increased internal bioerosion inshore may result in increased susceptibility of corals to dislodgement and fragmentation there.

Acknowledgements. We thank P. Alino, J. Fromont, A. G. Mackley, Y. McNeil, and the crew of the RV 'Harry Messel' for assistance in the field. We also thank A. G. Mackley for slabbing and digitizing the corals and for creating the resulting massive database; without his help, this study could not have been done. R. Matheson and the Department of Civil and Systems Engineering, James Cook University of North Queensland, graciously offered use of their rocksaws. G. Kershaw and the staff of the Radiogaphy Section. Townsville General Hospital offered their facilities and assistance for Xraying the corals. D. Johnson and $M$. Riddle provided helpful comments on the manuscript. This research was supported by the Australian Institute of Marine Science and the Natural Sciences and Engineering Research Council of Canada.

\section{LITERATURE CITED}

Acker, K. L., Risk, M. J. (1985). Substrate destruction and sediment production by the boring sponge Cliona caribband on Grand Cayman Island. J. sedim. Petrol. 55: 705-711

Andrews, J. C. (1983). Water masses, nutrient levels, and seasonal drift on the outer central Queensland Shelf (Great Barrier Reef). Aust. J. mar Freshwat. Res. 34: 821-834

Bellamy, N., Risk, M. J. (1982). Coral gas: oxygen production in Millepora on the Great Barrier Reef. Science 215: $1618-1619$

Bergman, K. M. (1983). Distribution and ecological significance of the boring Cliona viridis on the Great Barrier Reef. M. Sc. thesis, Department of Geology, McMaster University, Hamilton

Birkeland, C. E. (1987). Nutrient availability as a major determinant of differences among coastal hard-substratum communities in different regions of the tropics. In: Birkeland, C. E. (ed.) Comparison between Atlantic and Pacific tropical marine coastal ecosystems: community structure, ecological processes, and productivity. UNESCO Rep. mar. Sci. 46, p. 45-98

Birkeland, C. E. (in press). Geographic comparisons of coralreef community processes. Proc. Sixth Int. Coral Reef Congress, 1988, Townsville, Qld

Birkeland, C. E., Grosenbaugh, D. (1985). Ecological interactions between tropical coastal ecosystems. UNEP Regional Seas Reports and Studies, No. 73

Buss, L. W (1980). Bryozoan overgrowth interactions - the interdependence of competition for space and food. Nature Lond. 281 4 475-477

Carriker, M. R., Smith, E. H., Wilce, R. T (eds.) (1969). Penetration of calcium carbonate substrates by lower plants and invertebrates. AAAS Symp., Dallas, 1968. Am. Zool. 9: $626-1020$

Cloud, P. E., Jr (1959). Geology of Saipan, Mariana Islands. Part 4, Submarine topography and shoal-water ecology. U.S. Geol. Surv. Prof. Pap., No. 280 K, 361-445

Davies, P. J. (1983). Reef growth. In Barnes, D. J. (ed.) Perspectives on coral reefs. Brian Clouston Publ. (for Australian Inst. Mar Sci.), Canberra, p. 69-106

Dayton, P. K. (1971). Competition, disturbance, and community organization: the provision and subsequent utilization of space in a rocky intertidal community. Ecol. Monogr. 41 $351-389$

Frydl, P., Stearn, C. W. (1978). Rate of bioerosion by parrotfish in Barbados reef environments. J. sedim. Petrol. 48: 1149-1158

Guzman, H. M. (12986). Estructura de la communidad arrecifal de la Isla del Cano, y el efecto de perturbaciones naturales severas. M. Sc. thesis, Universidad de Costa Rica

Gygi, R. A. (1975). Sparisoma viride (Bonnaterre), the spotlight parrotfish, a major sediment producer on coral reefs of Bermuda? Eclog. geol. Helv. 68: 327-359

Hallock, P. (1988). The role of nutrient availability in bioerosion: consequences to carbonate buildups. Palaeogeogr., Plaeoclimatol., Palaeoecol. 53: 275-291

Hallock, P., Schlager, W. (1986). Nutrient excess and the demise of coral reefs and carbonate platforms. Paldios 1 389-398

Hein, F. J., Risk, M. J. (1975). Bioerosion of coral heads: inner patch reefs, Florida reef tract. Bull. mar Sci. 25: 133-138

Highsmith, R. C. (1980a). Geographic patterns of coral broerosion: a productivity hypothesis. J. exp. mar Biol. Ecol. 46: $177-196$

Highsmith, R. C. (1980b). Passive colonization and asexual colony multiplication in the massive coral, Porites lutea. J. exp. mar Biol. Ecol. 46: 55-67

Highsmith, R. C. (1981). Coral bioerosion at Enewetak: agents and dynamics. Int. Revue ges. Hydrobiol. 66: 335-375

Highsmith, R. C. (1982). Reproduction by fragmentation in corals Mar. Ecol. Prog. Ser 7:207-227

Highsmith, R. C., Lueptow, R. L., Schomberg, S. C. (1983). 
Growth and bioerosion of three massive corals on the Belize Barrier Reef. Mar. Ecol. Prog. Ser. 13: 261-271

Highsmith, R. C., Riggs, A., D'Antonio, C. (1980). Survival of hurricane-generated coral fragments and a disturbance model of reef calcification/growth rates. Oecologia (Berl.) 46: $322-329$

Hutchings, P. A. (1986). Biological destruction of coral reefs. A. review. Coral Reefs 4: 239-252

Ikeda, T., Carleton, J. H., Mitchell, A. W., Dixon, P. (1982). Ammonia and phosphate excretion by zooplankton from the inshore waters of the Great Barrier Reef. II. Their in situ contributions to nutrient regeneration. Aust. J. mar Freshwat. Res. 33: 683-698

Ikeda, T., Gilmartin, M. Revelante, N., Mitchell, A. W., Carleton, J. H., Dixon, P., Hutchinson, S. M., Hing Fay, E., Boto, G. M., Iseki, K. (1980). Biological, chemical and physical observations in inshore waters of the Great Barrier Reef, North Queensland 1975-1978. Australian Institute of Marine Science, Technical Bulletin, Oceanography Series No. 1

Klumpp, D. W., McKinnon, A. D., Mundy, C. N. (1988). Motile cryptofauna of a coral reef: abundance, distribution, and trophic potential. Mar. Ecol. Prog. Ser. 45: 95-108

Ogden, J. C. (1977). Carbonate sediment production by parrotfish and sea urchins on Caribbean reefs. In: Frost, S. H., Weiss, M. (eds.) Reefs and related carbonates - ecology and sedimentology. Am. Ass. Petrol. Geol. Stud. Geol., No. 4. p. $281-288$.

Randall, J. E. (1964). Sediment-producing fishes. Underwater Nat. 2: 30-32

Revelante, N., Gilmartin, M. (1982). Dynamics of phytoplankton in the Great Barrier Reef lagoon. J. Plankton Res. 4: $47-76$

Risk, M. J., Kramer, J. R. (1981). Water chemistry inside coral heads: determination of $\mathrm{pH}, \mathrm{Ca}$, and $\mathrm{Mg}$. Proc. 4th Int. Coral Reef Symp., Manila, p. 54 (abstr.)

Risk, M. J., MacGeachy, J. K. (1978). Aspects of bioerosion of modern Caribbean reefs. Revta Biol. trop. 26: 85-105

Risk, M. J., Muller, H. R. (1983). Porewater in coral heads evidence for nutrient regeneration. Limnol. Oceanogr. 28 $1004-1008$

Risk, M. J., Sammarco, P. W (1982). Bioerosion of corals and the influence of damselfish territoriality: a preliminary study. Oecologia (Berl.) 52: 376-380

Rose, C. S., Risk, M. J. (1985). Increase in Cliona delitrix investation of Montastrea cavernosa heads on an organically polluted portion of the Grand Cayman fringing reef P.S.Z.N.I. Mar. Ecol. 6: 345-364

Russ, G. (1984a). Abundances of herbivorous fishes and measures of food availability across the continental shelf in the central Great Barrier Reef region. UNESCO Rep. mar. Sci. 27: $63-73$

Russ, G. (1984b). Distribution and abundance of herbivorous grazing fishes in the central Great Barrier Reef. I. Levels of variability across the entire continental shelf. Mar. Ecol. Prog. Ser 20: 23-34

Russ, G (1984c). Distribution and abundance of herbivorous grazing fishes in the central Great Barrier Reef. II. Patterns of zonation of mid-shelf and outer-shelf reefs. Mar. Ecol. Prog. Ser. 20: 35-44

Rutzler, K. (1975). The role of burrowing sponges in bioerosion. Oecologia (Berl.) 19: 203-216

Rutzler, K., Reiger, G. (1973). Sponge burrowing: fine structure of Cliona lampa. Mar. Biol. 21: 144-162

Sammarco, P. W. (1980). Diadema and its relationship to coral spat mortality: grazing, competition, and biological disturbance. J. exp. mar. Biol. Ecol. 45: 245-272
Sammarco, P. W (1982). Echinoid grazing as a structuring force in coral communities: whole reef manipulations. J. exp. mar biol. Ecol. 61: 31-55.

Sammarco, P. W. (1985). Grazing fish and Great Barrier Reef Reflections (Great Barrier Reef Marine Park Authority) 15 $10-11$

Sammarco, P. W., Carleton, J. H., Risk, M. J. (1986). Effects of grazing and damselfish territoriality on bioerosion of dead corals: direct effects. J. exp. mar. Biol. Ecol. 98: 1-19

Sammarco, P. W., Crenshaw, H. C. (1984). Plankton community dynamics of the central Great Barrier Reef lagoon: analysis of data from Ikeda et al. Mar. Biol. 82: 167-180

Sammarco, P. W., Risk, M. J., Rose, C. (1987). Effects of grazing and damselfish territoriality on internal bioerosion of dead corals: indirect effects. J. exp. mar. Biol. Ecol. 112 185-199

Scoffin, T P., Stearn, C. W., Boucher, D., Frydl, P., Hawkins, C. M., Hunter, I. G., MacGeachy, J. K. (1980). Calcium carbonate budget of a fringing reef on the west coast of Barbados. Part II - erosion, sediments, and internal structure. Bull. mar. Sci. 30: 475-508

Scott, P. J. B., Cope, M. (in press). Tolo revisited: a re-survey of the corals in Tolo Harbour and Channel six years and half a million people later. In: Morton, B. (ed.) Proc. 2nd Int. Workshop on the Marine Flora and Fauna of Hong Kong and Southern China. Hong Kong University Press, Hong Kong

Scott, P. J. B., Risk, M. J. (1988). The effect of Lithophaga boreholes on the strength of the coral Porites lobata. Coral Reefs 7. 145-151

Scott, P. J. B., Carriquiry. J. D., Risk, M. J. (in press). El Niño, bioerosion, and the fate of the East Pacific Reefs. Proc. 6th Int. Coral Reef Congress 2: 517-520

Smith, S, V., Kimmerer, W. J., Laws, E. A., Brock, R. E., Walsh, T W (1981). Kaneohe Bay sewerage diversion experiment: perspectives on ecosystem responses to nutritional perturbation. Pacif. Sci. 35: 279-395

Sokal, R. R., Rohlf, F. J. (1981). Biometry. W H. Freeman, San Francisco

Steneck, R. S. (1982). A limpet-coralline alga association: adaptations and defenses between a selective herbivore and its prey. Ecology 63: 507-522

Steneck, R. S. (1983). Escalating herbivory and resulting adaptive trends in calcareous algal crusts. Paleobiology 9 $44-61$

Trudgill, S. T. (1976a). The marine erosion of limestones on Aldabra Atoll, Indian Ocean. Z. Geomorph. Suppl. 26: $164-200$

Trudgill, S. T (1976 b). The subaerial and subsoil erosion of limestones on Aldabra Atoll, Indian Ocean. Z. Geomorphol. Suppl. 26: 201-210

Tudhope, A. W. Risk, M. J. (1985). Rate of dissolution of carbonate sediments by microboring organisms, Davies Reef, Australia, J. sedim. Petrol. 55: 440-447

Tunnicliffe, V. (1978). The role of boring sponges in coral fracture. Colloques int. Cent. natn. Rech. scient. 291, Biologie des Spongiares, 309-315

Tunicliffe, V. (1981). Breakage and propagation of the stony coral Acropora cervicornis. Proc. Natl. Acad. Sci. U.S.A. 78: $2427-2431$

Tunicliffe, V. (1983). Caribbean staghorn coral populations: pre-Hurricane Allen conditions in Discovery Bay, Jamaica (West Indies). Bull. mar. Sci. 33: 132-151

Walker, T. A. (1981). Dependence of phytoplankton chlorophyll on bottom resuspension in Cleveland Bay, northern Queensland. Aust. J. mar. Freshwat. Res. 32: 981-986

Warme, J. E. (1975). Borings as trace fossils, and the processes 
of marine bioerosion. In: Frey, R. W. (ed.) The study of trace fossils. Springer-Verlag New York, p. 181-228

White, J. K. F. (1980). Distribution, recruitment, and development of the borer community in dead coral on shallow Hawailan reefs. Ph. D. dissertation, Department of Zoology, University of Hawaii at Manoa

Williams, D. M. (1982). Patterns in the distribution of fish communities across the central Great Barrier Reef. Coral Reefs 1: $35-43$

Williams, D. M. Hatcher, A. I. (1983). Structure of fish com-

This article was submitted to the editor munities on outer slopes of inshore, mid-shelf, and outer shelf reefs of the Great Barrier Reef. Mar. Ecol. Prog. Ser. 10: $239-250$

Zankl, H., Multer, H. G. (1977). Origin of some internal fabrics in holocene reef rocks, St. Croix, U S. Virgin Islands. In: Taylor, D. L. (ed.) Proc. 3rd Int. Coral Reef Symp., Vol. 2, p. $127-133$

Zeitzschel, B. (1978). Oceanographic factors influencing the distribution of plankton in space and time. Micropaleontology $24: 139-159$

Manuscript first received: April 6, 1989

Revised version accepted: August 22, 1989 